\title{
HTA of FELUDA diagnostic test for COVID-19
}

\author{
Kanchan Mukherjee \\ Professor \\ Centre for Health Policy, Planning and Management (CHPPM) \\ School of Health Systems Studies (SHSS) \\ Tata Institute of Social Sciences (TISS) \\ Mumbai, India \\ E mail: kanch@tiss.edu
}

Webpage: https://tiss.edu/view/9/employee/kanchan-mukherjee/

ORCID: https://orcid.org/0000-0002-3291-9172

\section{Highlights of this study}

First HTA on COVID-19 related health technology from India Provides evidence for guiding India's testing strategy for SARS-CoV-2 


\begin{abstract}
Testing capacity has been the achilles heel for most of the low- and low-middle income countries responding to the current COVID-19 pandemic. This has led to a number of innovations in health technology globally and India has been no exception. In this study, a Health Technology Assessment (HTA) was done on the recently indigenously developed innovative FELUDA test for SARS-CoV-2 diagnosis in India. The HTA shows that at the current price of INR 500 (USD 6.8), FELUDA is a cost effective test as compared to RT-PCR and Rapid Antigen Test (RAT). Since, field sensitivity and specificity is unknown for this test, it is recommended that the test be first piloted and monitored for field sensitivity and specificity before roll out. This is the first HTA on a COVID-19 related health technology from India and future HTA's at different points in the life cycle of FELUDA is recommended to guide policy.
\end{abstract}

Key words: Innovation, policy, testing strategy, entrepreneurship, India, sensitivity, specificity, cost effectiveness, SARS-CoV-2. 


\section{Introduction}

From the very early days of the Novel Corona Virus disease (COVID-19) pandemic, the World Health Organization (WHO) has been emphasizing the importance of testing as one of the key strategies in addressing the spread of the virus. ${ }^{1}$ Test-isolate-track/treat has been the golden rule but its implementation has been constrained by availability of resources (financial, skilled human resources, infrastructure) and dependency on imports, especially in the low-and low-middle income countries. India has been no exception and while ranked second globally in terms of number of severe acute respiratory syndrome coronavirus-2 (SARS-CoV-2) cases, it is ranked $105^{\text {th }}$ in the world (as on October 12, 2020) in global comparison of its population testing rate. ${ }^{2}$

It is in times like these that innovation and entrepreneurship can play a key role and COVID-19 has opened a window of opportunity for innovations across multiple sectors. One of the biggest drivers of this innovation is health technolog $\mathrm{y}^{3}$ which by definition includes interventions (like a test) developed to diagnose a medical condition. Health technology Assessment (HTA) is a multidisciplinary process that uses explicit methods to determine the value of a health technology to inform decision-making for promoting an equitable, efficient, and high-quality health system. ${ }^{4}$ While the use of HTA to inform policy decisions is well established in the high income and upper middle income countries, its use and application in health systems has been limited in low- and low-middle income countries. ${ }^{5,6}$ With a plethora of technologies being developed to address the COVID-19 situation, the role of HTA in addressing medical, ethical, economic and social implications of a policy decision becomes even more important. In this context, this study is the first HTA of a recent indigenously developed health technology called the FNCAS9 Editor-Limited Uniform Detection Assay (FELUDA) diagnostic test to provide recommendations for India's COVID-19 testing policy.

\section{Methodology}

This is a study based on secondary data available open access in the public domain. Testing guidelines, costs and effectiveness (sensitivity and specificity) data reported regarding current COVID-19 diagnostic tests have been used for comparative analysis. The market price of the test has been used to calculate the direct testing costs from the societal perspective. Media reports and official government web sites have been used to identify the price and sensitivity and specificity parameters of the tests in the Indian context. Data on new tests per day smoothed, based on official Indian data, available from our world in data database (www.ourworldindata.org) has been used for the analysis. A Health Technology Assessment (HTA) was done to assess the implications of FELUDA test on India's testing strategy.

\section{Results}

India's current testing strategy permits the use of two types of tests for diagnosing SARS-CoV-2. The two diagnostic tests are Reverse Transcriptase- Polymerase Chain Reaction (RT-PCR) and Rapid antigen test (RAT). The RT-PCR is currently considered as the gold standard with high sensitivity and specificity but the sensitivity of RAT is only moderate resulting in higher chances of false negatives. Hence, the testing strategy advisory issued on June $23^{7}$ and subsequent advisories $^{8,9}$ insist on a RT-PCR follow up test for those symptomatic testing negative by RAT to 
rule out false negatives. Studies and reports have shown that the implementation of this follow up testing has been weak by the states/union territories (UT), since RT-PCR is a cost and skill intensive exercise. ${ }^{10}$

The market price of RT-PCR had initially been capped to INR 4500 (USD 61) across India and subsequently the cap was removed and states were asked to negotiate and decide on the price of this test. With the better availability of reagents for RT-PCR and personal protective equipment (PPE), the price of RT-PCR has been reducing. The current market price (October 12, 2020) of RT-PCR test for COVID-19 varies across states and is in the range of INR 1200 to 2750 (USD 16 - 37.5). The current market price of RAT is in the range of INR 450-700 (USD 6 - 9.5). The Drug Controller General of India (DCGI) recently (September 2020) approved a novel indigenous developed paper based diagnostic test named 'FELUDA'. ${ }^{11}$ This test is based on Clustered Regularly Interspaced Short Palindromic Repeats (CRISPR) technology and was successfully innovated to be used as a diagnostic tool for SARS-CoV-2. ${ }^{12}$ While the method of swab collection in this test remains the same as that of RT-PCR and RAT, the results of this test can be read with the naked eye like a pregnancy test within 45 minutes. This innovative diagnostic test has been reported to be $96 \%$ sensitive and $98 \%$ specific. ${ }^{11}$ It has a much quicker turnaround time than RT-PCR and requires less expensive equipment. The FELUDA test is being considered to be marketed at a price of INR 500 (US\$ 6.8). Table 1 shows key differences between these three tests.

Table 1: Key differences between COVID-19 diagnostic tests currently used in India.

\begin{tabular}{|c|c|c|c|c|}
\hline Test & Cost (INR) & $\begin{array}{l}\text { Time taken to } \\
\text { give results }\end{array}$ & $\begin{array}{c}\text { Sensitivity and } \\
\text { Specificity } \\
\text { (Lab data) }\end{array}$ & $\begin{array}{c}\text { Additional } \\
\text { findings }\end{array}$ \\
\hline RT-PCR & $1200-2750$ & 90 minutes & $\begin{array}{c}\text { Sensitivity- 95\% } \\
\text { Specificity-99\% }\end{array}$ & $\begin{array}{c}\text { Requires } \\
\text { expensive } \\
\text { equipment and } \\
\text { reagents, skilled } \\
\text { personnel and } \\
\text { specialized } \\
\text { laboratories. } \\
\text { Imports involved. }\end{array}$ \\
\hline
\end{tabular}




\begin{tabular}{|c|c|c|c|c|}
\hline RAT & $\begin{array}{l}\quad 450-700 \\
\text { Average cost: } \\
575\end{array}$ & 30 minutes & $\begin{array}{l}\text { Sensitivity- } \\
50-84 \% \\
\text { Specificity- } \\
99-100 \%\end{array}$ & $\begin{array}{c}\text { Requires less } \\
\text { specialized } \\
\text { chemicals, } \\
\text { equipment and } \\
\text { skills. Imports } \\
\text { involved. Field } \\
\text { sensitivity } \\
\text { reported to be } \\
50-60 \% \text {. Adjunct } \\
\text { RT-PCR required } \\
\text { to rule out false } \\
\text { negatives }\end{array}$ \\
\hline FELUDA & 500 & 45 minutes & $\begin{array}{l}\text { Sensitivity- } 96 \% \\
\text { Specificity- } 98 \%\end{array}$ & $\begin{array}{c}\text { Quicker } \\
\text { turnaround time, } \\
\text { less expensive } \\
\text { equipment and } \\
\text { reagents } \\
\text { involved. Does } \\
\text { not require } \\
\text { specialized lab or } \\
\text { skilled personnel } \\
\text { Not dependent on } \\
\text { imports. Can also } \\
\text { detect other } \\
\text { viruses (e.g. } \\
\text { SARS-1) and can } \\
\text { be developed to } \\
\text { detect more. }\end{array}$ \\
\hline
\end{tabular}

\section{Discussion}

The implications of this HTA on testing policy is discussed through the following three comparative scenarios.

Scenario I: Earlier testing strategy through RT-PCR

Scenario II: Current testing strategy (RAT + RT-PCR)

Scenario III: FELUDA as a testing strategy

The RAT test used in India has an analytical (lab) specificity of 99\%-100\% and sensitivity in the range of 50\%-84\% ${ }^{13}$, implying that the false negative rates are in the range of $16 \%-50 \%$. Considering that this proportion of people would require adjunct RT-PCR as per current testing strategy, the mean value of this range (33\%) was selected for the proportional calculation of costs for RT-PCR in scenario II. Using the data on simple exponential smoothing (SES) forecast 
on new tests conducted per day on October $12,{ }^{14}$ the existing average market prices of these tests and sensitivity and specificity values (table 1); the cost implications and associated issues of these three scenarios are presented in table 2.

Table 2: Implications for testing policy

\begin{tabular}{|c|c|c|c|c|c|}
\hline $\begin{array}{l}\text { Testing } \\
\text { scenarios }\end{array}$ & $\begin{array}{c}\text { New Tests } \\
\text { /day } \\
\text { (Smoothed) } \\
\text { (As on Oct 12, } \\
2020)\end{array}$ & $\begin{array}{c}\text { Average } \\
\text { Cost } \\
\text { (INR) }\end{array}$ & $\begin{array}{c}\text { Cost of testing/ } \\
\text { day }\end{array}$ & Issues & $\begin{array}{c}\text { Comparative } \\
\text { Analysis }\end{array}$ \\
\hline $\begin{array}{c}\text { I } \\
\text { (RT-PCR) } \\
\text { Previous } \\
\text { testing policy }\end{array}$ & 1127100 & 1975 & $\begin{array}{c}2226022500 \\
\text { (INR } 2.2 \\
\text { Billion) } \\
\text { (USD } 30 \\
\text { million) }\end{array}$ & $\begin{array}{c}\text { Need for } \\
\text { specialized } \\
\text { labs and } \\
\text { skilled human } \\
\text { resources }\end{array}$ & $\begin{array}{l}\text { High on cost } \\
\text { and high on } \\
\text { effectiveness }\end{array}$ \\
\hline $\begin{array}{c}\text { II } \\
\text { (RAT+ RT- } \\
\text { PCR) } \\
\text { Current testing } \\
\text { policy }\end{array}$ & 1127100 & $\begin{array}{c}575 \\
(\mathrm{RAT}) \\
\text { and } \\
1975 \\
(\mathrm{RT}- \\
\mathrm{PCR})\end{array}$ & $\begin{array}{l}1382669925 \\
\text { (INR } 1.3 \\
\text { Billion) } \\
\text { (USD } 17.7 \\
\text { million) }\end{array}$ & $\begin{array}{c}\text { Poor } \\
\text { compliance } \\
\text { leading to } \\
\text { increased } \\
\text { societal costs } \\
\text { due to false } \\
\text { negatives. } \\
\text { Field } \\
\text { sensitivity } \\
\text { reported to be } \\
\text { lower. }\end{array}$ & $\begin{array}{l}\text { High on costs } \\
\text { and low on } \\
\text { effectiveness }\end{array}$ \\
\hline $\begin{array}{c}\text { III } \\
(\text { FELUDA) }\end{array}$ & 1127100 & 500 & $\begin{array}{c}563550000 \\
\text { (INR } 0.5 \text { billion) } \\
\text { (USD } 6.8 \\
\text { million) }\end{array}$ & $\begin{array}{c}\text { Field } \\
\text { sensitivity and } \\
\text { specificity not } \\
\text { known. }\end{array}$ & $\begin{array}{l}\text { Low on cost } \\
\text { and high on } \\
\text { effectiveness }\end{array}$ \\
\hline
\end{tabular}




\section{Conclusions}

The HTA shows that the FELUDA test at the price of INR 500 per test, is the most cost-effective testing strategy currently among these three diagnostic tests and has the potential to improve India's testing capacity. At the current rate of testing and market price, it would bring down the testing cost in the country by almost a third and save around INR 800 million (approximately USD 11 million) per day. In addition, the added benefits of shorter turnaround time, ease of doing the test and interpretation would increase accessibility of testing and enhance the testing rates in India. FELUDA test also address the social and ethical dimensions associated with the improper implementation of the current testing strategy. However, it is important to monitor the field sensitivity and specificity of this test.

Based on this HTA, it is recommended that the FELUDA test be first piloted in those districts/states having the lowest compliance to RT-PCR and monitored to analyse the field effectiveness data. If field sensitivity and specificity are similar to the RT-PCR, it can be rolled out across the country at the current price. If the field sensitivity is moderate (like the current RAT), then adjunct RT-PCR will need to be done. Future HTA's at different points in the life cycle of FELUDA is recommended. With the DCGI already approving FELUDA for commercial launch, it is important that the testing strategy aligns itself to this reality at the earliest to facilitate a smooth convergence of science, technology, innovation and policy.

\section{References}

1. World Health Organization (WHO). Emergencies Press Conference on corona virus disease outbreak. (March18,2020). Available from: https://www.who.int/docs/defaultsource/coronaviruse/transcripts/who-audio-emergencies-coronavirus-press-conference-full18mar2020b4d4018fc1904605831b6a08d31e0cbc.pdf?sfvrsn=1f444736_8.

2.CoronaUpdate(October 12, 2020).Available from: https://www.worldometers.info/coronavirus/

3. HTA Glossary. Available from: http://htaglossary.net/health+technology

4. O'Rourke B, Oortwijn W, Schuller T, the International Joint Task Group (2020). The new definition of health technology assessment: A milestone in international collaboration. International Journal of Technology Assessment in Health Care 1-4. https://doi.org/10.1017/S0266462320000215

5. Mukherjee K, Haycox A, Walley T (2017). Health technology assessment: a potential road map for India. Int J Med Sci Public Health, 2017; 6:5: 969-973. Available from:

http://www.ijmsph.com/?mno=252960

6. Mukherjee K. A SMART framework for HTA capability development: Lessons from India. Health Policy and Technology. March 2020; 9 (1) :42-44. Available from: https://www.sciencedirect.com/science/article/pii/S2211883719300826

7. ICMR. Advisory. Newer Additional Strategies for COVID-19 Testing. June 23, 2020. https://www.icmr.gov.in/pdf/covid/strategy/New_additional_Advisory_23062020_3.pdf 
8. MOHFW and ICMR. Letter to Chief Secretary/ Administrator/ Advisor to Governor/ Advisor to Lt. Governor for Empowering citizens for testing of SARS-CoV-2 virus to save precious lives and contain the virus. July 1, 2020.

https://www.icmr.gov.in/pdf/covid/strategy/Joint_Letter_Test_Track_Treat.pdf

9. ICMR. Advisory on Strategy for COVID-19 Testing in India. Available from: https://www.icmr.gov.in/pdf/covid/strategy/Testing_Strategy_v6_04092020.pdf

10. Mukherjee K. A comparative analysis of the lockdown and unlock policies on the COVID-19 situation in India. Cambridge Open Engage 2020. doi:10.33774/coe-2020-fdqtr.

11. Press Information Bureau. Govt. of India (September 19, 2020). Available from: https://pib.nic.in/PressReleseDetail.aspx?PRID=1656770

12. Mohd. Azhar et. al. (September 14, 2020). Rapid, accurate, nucleobase detection using FnCas9. MedRxiv 2020.09.13.20193581; doi: https://doi.org/10.1101/2020.09.13.20193581

13. ICMR. Advisory on Use of Rapid Antigen Detection Test for COVID-19. Available form: https://www.icmr.gov.in/pdf/covid/strategy/Advisory_for_rapid_antigen_test14062020.pdf

14. Hasell, J., Mathieu, E., Beltekian, D. et al. (2020). A cross-country database of COVID-19 testing. Sci Data 7, 345. 